\title{
IMPLEMENTASI PEMBELAJARAN SHOOTING BOLA BASKET BERBASIS VIDIO DI STKIP PASUNDAN
}

\author{
Ruslan Rusmana1, Budiman² \\ 1,2 STKIP Pasundan \\ E-mail: ruslan.rusmana24@gmail.com¹, budiimann13@gmail.com² \\ DOI: https://doi.org/10.36526/kejaora.v6i2.1558
}

\begin{abstract}
ABSTRAK
Penelitian ini bertujuan untuk mengetahui hasil belajar keterampilan lay up shoot bola basket pada mahasiswa prodi PJKR STKIP Pasundan. Subjek penelitian adalah 25 orang mahasiswa. Penelitian ini menggunakan metode penelitian desain eksperimen. Keterampilan yang dinilai adalah hasil tembakan dari tiga kali kesempatan dan diambil yang terbaik dengan menggunakan teknik total sampling mahasiwa tingkat dua yang mengikuti perkuliahan bola basket. Berdasarkan output diperoleh nilai Sig.(2-tailed) sebesar 0,038 >0,05, maka sesuai dasar pengambilan keputusan Paired Samples Test, maka dapat disimpukan Ho diteriam Hi ditolak, yang artinya bahwa tidak terdapat pengaruh signifikan implementasi video pembelajaran terhadap hasil lay up dalam permainan bola basket.
\end{abstract}

Kata Kunci: Implementasi, Pembelajaran, Bola Basket, Shooting Lay Up.

\section{PENDAHULUAN}

Kondisi di tengah wabah virus COVID19 saat ini memaksa semua orang untuk dapat beradaptasi dalam melakukan aktivitasnya salah satunya dalam proses pembelajaran bagi mahasiswa pendidikan jasmani kesehatan dan rekreasi STKIP Pasundan dalam mengikuti mata kuliah bola basket pada semester ganjil tahun akademik 2020-2021 yang biasanya dilakukan secara tatap muka atau offline akan tetapi sekarang arus dilakukan secara daring, merujuk apa yang di ungkapkan (Argaheni, 2020) daring dapat meningkatkan pemerataan akses dan perluasan pendidikan karena hasil peneleitian (Subiakto, 2013) harus diakui bahwa teknologi komunikasi sudah masuk di desa-desa. Juga hasil penelitian (Ilham \& Oktafiranda, 2021) hasil lapangan e-learning dengan persentase $84,44 \%$. Hal tersebut tentu berbeda dengan apa yang dilihat oleh peneliti dilapangan yang mana pembelajaran secara daring masih banyak kendala karena keterbatasan insfrastruktur internet yang belum merata kesemua daerah. Hasil penelitian (Rosnaeni \& Prastowo, 2021) kendala pembelajaran jarak jauh diantaranya terbatasnya perangkat pembelajaran dan akses internet, latar belakan pendidikan orang tua dan tugas menumpuk terlalu banyak sehingga membuat minat belajar menjadi menurun.

Dampak covid-19 menjadikan bertranspormasi pada teknologi pendidikan di Indonesia (Muskania \& Zulela MS, 2021). Pelaksanaan pembelajaran secara daring sebetulnya bukan hanya karena ada pandemi covid-19 tapi sudah menjadi suatu eharusan tuntutan perkembangan zaman yang semakin kesini inovasi teknologi berubah begitu cepat.

Kebijakan pemerintah tentang pelaksanaan pembelajaran daring selama pandemi covid 19 menjadi tangtangan pembelajaran digital bagi dunia pendidikan terutama dalam pembelajaran jasmani yang cenderung lebih banyak melakukan praktek di banding teori. Sebetulnya sebelum masa covid 19 pengaruh teknologi dalam kehidupan di masyarakat sangat signifikan, terutama bagi anak-anak digambarkan. Saat ini anak-anak digambarkan sebagai digital natives dan dianggap lebih kompeten dalam menngunakan teknologi (Ahlgrim-Delzell \& Rivera, 2015). Saat ini fenomena yang saya amati dilapangangan ada beberapa 
permasalahan diantaranya masih belum meratanya koneksi internet ke semua daerah, masih kurangnya literasi pembelajaran bola basket secara daring, model pembelajaran bola basket secara daring yang menyenangkan dan belum adanya sistem aplikasi android yang khusus untuk pembelajaran bola basket secara daring, namun masalah tersebut menjadi peluang bagi reseacher untuk meneliti model pembelajaran bola basket di sekolah secara daring karena sampai dengan hari ini pembelajaran bola basket di sekolah sperti mati suri karena lapangan bola basket dan sekolah ditutup digantikan dengan pembelajaran secara daring demi mencegah penyebaran covid 19. Dibutuhkan suatu model pembelajaran bola basket yang dapat menyesuaikan sesuai situasi dan kondisi atau memodifikasi pembelajaran bola basket.

Organisasi kesehatan dunia (WHO) pada 11 maret 2020 telah menyatakan wabah virus corona (covid-19) sebagai pandemi global (Cucinotta, 2020). Termasuk di Indonesia pemerintah mengeluarkan kebijan physical distancing sebagai langkah ikhtiar agar tidak terkena dampak dari pandemi Covid-19 karena belum pasti kapan akan berakhir, biarpun keselamatan merupakan hal yang paling utama akan tetapi pembelajaran di semua jenjang pendidikan harus tetap dilaksanakan maka dari itu Pembelajaran Jarak Jauh atau daring sebagai salah satu solusi cara untuk mengimplementasikan tujuan pembelajaran. Diperkuat dengan kebijakan pemerintah melalui menteri pendidikan dan kebudayaan yang menyatakan bahwa pihaknya akan mengupayakan digitalisasi pembelajaran pada 2021. Ini dilakukan salah satunya untuk mngantisipasi pembelajaran secara digital seperti yang dilaksanakan selama pandemi karena mau tidak mau kitapun harus menyesuaikan dengan perkembangan zaman dengan penuh kemajuan teknologi di era disrupsi 4.0 dimana semuanya menjadi lebih mudah, lebih cepat dan ekonomis.

Kaitan dengan hal tersebut hasil survei peneiti dilapangan ketika mengajar mata kuliah bola basket di PJKR STKIP Pasundan pada tahun 2018 peneliti menggunakan metode part method dalam meningkatkan hasil belajar keterampilan layup bola basket terjadi peningkatan keterampilannya sebesar 18\% (Akhmad Sobarna, Ruslan Rusmana, 2018). Peneliti merasa perlu jika penelitian tersebut dilaksanakan lagi dengan pengembangan media vidio yang disesuaikan dengan kondisi pandemi covid-19 juga perkembangan digitlasasi pendidikan seperti yang di gemborgemborkan mentri pendidikan tentang kampus merdeka.

Urgensi dari penelitian ini perkembangan teknologi pasti akan terjadi dan jika kita menghindarinya maka akan tertinggal dari suatu generasi kemudian kondisi pandemi covid-19 belum ada kepastian kapan akan berakhir maka dari itu implementasi pembelajaran daring layup bola basket berbasis vidio sangat tepat karena saat ini yang paling efektif untuk pembelajaran keterampilan gerak adalah dengan menggunakan vidio baik itu dari hasil berselancar di internet seperti bahan dari yotube atau vidio lainnya.

Berdasakan analisisa peneliti sumber belajar mata kuliah praktek saat ini yang paling banyk digunakan oleh mahasiswa dan dosen adalah dari vidio, kenapa mengambil keterampilan layup karena keterampilan ini kalau dilihat dari segi teori merupakan teknik yang paling gampang kedua dalam banyak jenis shooting karena jaraknya dekat kemudian posisi lepasan terakhir lebih dekat ke keranjang dibanding jenis shooting lainnya. Meskipun keterampilan layup merupakan keterampilan dasar yang relatif mudah dilakukan akan tetapi masih banyak pemain bola basket yang melenceng dalam memasukan bola ke dalam keranjang. Mungkin banyak faktor yang mempengaruhinya diantaranya teknik yang salah, faktor psikologi atau faktor fisik yang tidak mendukung. Persentase temabakan tertinggi adalah tembakan layup yang dilakukan pemain yang berada dengan jarak yang dekat dengan keranjang. Posisi yang dekat dengan keranjang harusnya memiliki persentase yang lebih tinggi ketika melakyukan tembakan. Selain faktor teknik, fisik dan psikologi penulis meyakini bahwa perrlu adanya tambahan medi ketia belajr atau berlatih maka dari itu penulis akan 
Jurnal Kejaora: Jurnal Kesehatan Jasmani dan Olah Raga

ISSN: 2541-5042 (Online)

ISSN: 2503-2976 (Print)

Volume 6 Nomor 2, Edisi November 2021

meneliti tentang bagaimana dampak atau pengaruh dari hasil pembelajaran dengan metode daring berbasis vidio ini. maka dari itu peneliti meyakini penelitian ini sangat penting dengan judul besar implementasi pembelajaran daring layup bola basket berbasis vidio di STKIP Pasundan.

Implementasi pembelajaran secara daring, online atau lebih dikenal dalam dunia pendidikan disebut dengan pendidikan jarak jauh dan bahasa modern nya digitalisasi pendidikan yaitu pembelajaran yang memnggunakan model interaktif berbasis internet dan learning manajemen system, memang membutuhkan strategi yang tepat dalam pemilihan bahan, media serat metode mengajar terutama dalam mata kuliah praktek. (Guasch,Espasha \& meli,2019) dalam pembelajaran online yang mempunyai peran kunci implementasi pembelajaran adalah yang memberikan umpan balik. Yang memberikan umpan balik disini adalah mahasiswa atau siswa bagaimana agar siswa dapat memberikan umpan balik terhadap materi keterampilan gerak yang diberikan oleh dosen. sebagian besar dibandingkan tetapi agar pembelajaran online menjadi efektif dan efisien, dosen, organisasi, dan institusi harus memiliki pemahaman yang komprehensif tentang manfaat dan batasannya (Adedoyin \& Soykan, 2020). Semua elemen harus memiliki persepsi sudut pandang yang sama antara mahasiswa, dosen dan lembaga. Pembelajaran telah berubah secara dramatis satu kebutuhan mendesak bagi pendidik adalah mengintegrasikan teknologi ke dalam pengaturan kelas untuk meningkatkan kinerja siswa namun pendidik secara internasional dihadapkan pada tantangan yang semakin meningkat untuk memasukkan teknologi ke dalam praktik pedagogis mereka dengan sukses (Shan li, Juan zheng \& Yufeng Zhen, 2018). Selain itu Program pendidikan jarak jauh memberikan peserta didik menjadi lebih fleksibilitas dan akses ke dalam pembelajaran, mungkin tidak akan bisa mengikuti jika banyak pembelajaran jika tidakada PJJ. Program pendidikan jarak jauh menjadi semakin populer karena institusi tidak hanya ingin memangkas biaya, tetapi juga memperluasnya daerah tradisional

tanpa berinvestasi dalam (Beban \& Dosen, 2020)operasi bangunan gedung (Goad Tyler et al, 2020).

Dalam permainan (Hampson et al., 2020) bola basket terdapat beberapa teknik atau keterampilan yaitu Passing, dribbling \& shooting. Pada bahasan ini kami akan berfokus pada shooting menurut (FIBA, 2018) ada beberapa jenis shooting diantaranya free-throw yang merupakan tembakan ketika bola dalam pegangan tangan atau kedua tangan seorang pemain dan kemudian dilemparkan ke arah keranjang, tepisan adalah ketika bola diarahkan dengan menggunakan tangan atau kedua tangan kearah keranjang dan dunk adalah ketika bola dilesahkan kebawah masuk kedalam keranjang lawan dengan satu atau kedua tangan. Layup merupakan pengebangan dari jenis tembakan juga, (Brown \& Brown, 2016) salah satu teknik terpenting dalam bola basket adalah layup. Kesuksesan dalam melakukan layup ketika dalam pertandingan sangat mempengaruhi hasil pertandingan karena layup persentasenya sangat sering dilakukan oleh setiap pemain bola basket dilapangan.

Menembak adalah daya tarik bagi pemain untuk untuk bermain bola basket, teknik ini paling di gemari karena setiap pemain mempunyai untuk mencetak skor (Vic Amber, 2012). Coba saja berikan kepada pemain ketika berada dilapangan sendirian pasti mereka nalurinya ingin melakukan tembkan ke keranjang dan tembakan juga merupakan finising penentu kemenangan setelah dribbling dan passing. (Donovan, 2010) Menembak adalah keterampilan yang paling pppuler bagi semua usia dan semua tingkat. Banyak jenis jenis tembakan diantaranya layup, free throw, jum shoot dan hook shoot. Kemudian jenis tembakan tersebut harus dilatihkan sesuai dengan desain situasi pertandingan yang sangat sulit dan selalu berubah. Ingatkan para pelajar bahwa dalam mempelajari keterampilan dengan benar memasukan bola ke keranjang hanyalah salah satu tolak ukur keberhasilan.

Permaslahan yang terjadi salah satunya pada pelaksanaan perkuliahan mata kuliah bola basket di program studi Pendidikan Jasmani Kesehatan dan Rekreasi 
Jurnal Kejaora: Jurnal Kesehatan Jasmani dan Olah Raga

ISSN: 2541-5042 (Online)

ISSN: 2503-2976 (Print)

Volume 6 Nomor 2, Edisi November 2021

STKIP Pasundan dari dulu perkuliahan selalu dilaksanakan secara tatap muka yang dianggap lebih baik dengan hari ini karena dampak dari covid-19 pembelajaran dilaksanakan secara daring. Maka hal tersebut yang menadi pertanyaan kami sebagai peneliti untuk melaksanakan penelitian mengetahui perihal efektivitas pelaksanaan perkuliahan di PJKR STKIP Pasundan. Kalau pembelajaran dilaksanakan secara daring tapi kita mempersiapkan segala sesuatunya dengan baik saya kira akan membuat hasil pembelajaranpun berhasil.

Tujuan dari penelitian ini berdasarkanbeberapa pernyataan dan teori diatas perlu kiranya saya menyampaikan tujuan dalam penelitian ini yaitu perlunya obat atau solusi untuk mengatasi pembelajaran secara daring lebih efektif dengan tema besar memberikan materi secara daring berbasis vidio pada perkuliahan bola basket pada mahasiswa PJKR STKIP Pasundan.

\section{METODE}

Desain penelitian yang digunakan karena keterbatasan situasi dan kondisi

pandemi covid 19 maka penelitian ini menggunakan metode penelitian dengan desain eksperimen tanpa kelompok kontrol dengan jumlah sampel menggunakan total sampling sebanyak 25 orang. Pegumpulan data dilakukan dengan menggunakan instrumen tes layup shoot bola basket yang dibuat oleh peneliti dan telah di uji validitas dan realibilirtasnya.

\section{HASIL DAN PEMBAHASAN}

Implementasi pembelajaran shooting lay up bola basket berbasis vidio tidak memberikan pengaruh yang signifikan. Persyaratan pengujian analisis data yang pertama adalah menguji normalitas. Uji normalitas yang digunakan dalam penelitian ini adalah uji one kolmogorov smirnovz melalui IBM SPSS 25 dengan ketentuan apabila nilai signifikansi kurang dari 0,05 (Sig. $<0,05$ ) maka data berdistribusi tidak normal, sedangkan apbila nilai signifikansi lebih dari 0,05 (Sig. > 0,05) maka data berdistribusi normal. Hasil perhitungan uji normalitas data hasil lay up dapat dilihat pada tabel 1 .

Tabel 1. Hasil uji normalitas data kelompok eksperimen.

\begin{tabular}{lccc}
\hline & Kolmogrov-smirnov & Asymp. (2-tailed) & Ket \\
\hline $\begin{array}{l}\text { Pretest kelompok } \\
\text { eksperimen }\end{array}$ & 0,145 & 0,185 & $\begin{array}{c}\text { Data } \\
\text { Normal }\end{array}$ \\
\hline $\begin{array}{l}\text { Postes kelompok } \\
\text { eksperimen }\end{array}$ & 0,125 & 0,139 & $\begin{array}{c}\text { Data } \\
\text { Normal }\end{array}$ \\
\hline
\end{tabular}

Dari hasil output diatas dapat dipaparkan hasil sebagai berikut: 1) Tabel uji normalitas di atas menunjukan untuk data hasil lay up pada pretest kelompok eksperimen diketahui bahwa nilai $\mathrm{KS}=0,145$ dan Signifikansi (Sig.) $=0,185>0,05$ maka Ho diterima, dengan demikian distribusi data dinyatakan normal; 2) Untuk data hasil lay up posttest kelompok eksperimen dengan nilai KS $=0,152$ dan Signifikansi (Sig.) $=0,139>$ 0,05 maka Ho diterima, dengan demikian distribusi data dinyatakan normal.
Langkah berikutnya untuk persyaratan pengujian statistik adalah uji homogenitas. Statistik yang digunakan untuk menguji homogenitas adalah uji statistik One Way Anova melalui IBM SPSS 25 dengan ketentuan apabila (Sig.) $>0,05$ maka data homogen, sedangkan bila (Sig.) $<0,05$ data tidak homogen. Hasil perhitungan uji homogenitas data hasil lay up pretest dan posttest pada kelompok eksperimen dapat dilihat pada tabel 2:

Tabel 2. Hasil uji homogenitas hasil Pretest dan Posttest kelompok eksperimen.

\begin{tabular}{lll}
\hline Leven statistic & Sig. (2-tailed) & Ket \\
\hline
\end{tabular}


Jurnal Kejaora: Jurnal Kesehatan Jasmani dan Olah Raga

ISSN: 2541-5042 (Online)

ISSN: 2503-2976 (Print)

Volume 6 Nomor 2, Edisi November 2021

\begin{tabular}{llll}
\hline Pretest dan postest & 0,132 & 0,579 & Data Homogenl
\end{tabular}

kelompok eksperimen

Dari tabel di atas perhitungan uji homogenitas pada pretest dan Posttest kelompok ekperimen diketahui bahwa nilai leven statistic $=0,312$ dan signifikansi (Sig.) $=$ $0,579>0,05$ maka Ho diterima, dengan demikian distribusi data dinyatakan homogeny.
Statistik yang digunakan untuk menguji hipotesis adalah uji statistik paired samples test melalui IBM SPSS 25. Berikut adalah data hasil pengujian paired sample test, dapat dilihat pada tabel 3 .

Tabel 3. Uji paired sample test pada kelompok eksperimen

\begin{tabular}{lllll}
\hline & $\mathrm{T}$ & $\begin{array}{l}\text { Sig. (2- } \\
\text { tailed) }\end{array}$ & Keputusan & Kesimpulan F \\
\hline $\begin{array}{l}\text { Kelompok } \\
\text { eksperimen }\end{array}$ & $-2,191$ & 0,185 & Ho Ditolak & Pengaruh signifikan \\
\hline
\end{tabular}

Dasar pengujian untuk uji pengaruh data adalah sebagai berikut:

Hipotesis:

a) $\mathrm{H}_{0}=$ Tidak terdapat Pengaruh signifikan implementasi video pembelajaran terhadap hasil lay up dalam permainan bola basket

b) $\mathrm{H}_{1}=$ Terdapat Pengaruh signifikan implementasi video pembelajaran terhadap hasil lay up dalam permainan bola basket

Kriteria Keputusan:

1. Nilai Signifikansi atau nilai probabilitas $>0,05$, Ho diterima dan Hi ditolak

2. Nilai Signifikansi atau nilai probabilitas $<0,05$, Ho ditolak dan $\mathrm{Hi}$ diterima

Keputusan:

Berdasarkan output diata diperoleh nilai Sig.(2-tailed) sebesar 0,038 > 0,05, maka sesuai dasar pengambilan keputusan Paired Samples Test, maka dapat disimpukan Ho diteriam Hi ditolak, yang artinya bahwa tidak terdapat pengaruh signifikan implementasi video pembelajaran terhadap hasil lay up dalam permainan bola basket.

\section{KESIMPULAN}

Berdasarkan dari data yang peneliti peroleh dari lapangan dan pembahasan hasil penelitian dapat disimpulkan bahwa tidak terdapat pengaruh yang signifikan pada implementasi pembelajaran shooting layup bola basket secara daring karena mahasiswa rata-rata hanya memahami secara terori saja tanpa melakukan latihan secara kontinyu, Untuk mata kuliah praktik lebih baik dilaksanakan secara langsung karena yang namanya praktek perlu tahapan belajar yang tepat dan pengulangan yang banyak supaya terjadi otomatisasi dalam melakukan keterampilan termasuk dalam melakukan ketrampilan layup shoot bola basket, Perlu penelitian lanjutan karena hasil dari penelitian ini menunjukankan bahawa implementasi belajar keterampilayan shooting layup bola basket tidak signifikan berbeda dengan beberapa penelitian sebelumnya.

\section{UCAPAN TERIMA KASIH}

Kami ucapkan terimakasih kepada kepada semua pihak yang telah memberikan bantuan baik secara materil maupun moril atas terlaksana dan selesasinya penelitian ini. Terutama kepada KEMENDIKBUDRISTEK dan STKIP Pasundan yang memberikan kontribusi sangat besar.

\section{DAFTAR PUSTAKA}

Ahlgrim-Delzell, L., \& Rivera, C. (2015). A Content Comparison of Literacy Lessons from 2004 and 2010 for Students with Moderate and Severe Intellectual Disability. Exceptionality, 23(4), 258-269. https://doi.org/10.1080/09362835.2015 
Jurnal Kejaora: Jurnal Kesehatan Jasmani dan Olah Raga

ISSN: 2541-5042 (Online)

ISSN: 2503-2976 (Print)

Volume 6 Nomor 2, Edisi November 2021

.1064417

Akhmad Sobarna, Ruslan Rusmana, Y. M. (2018). MENINGKATAN HASIL BELAJAR LAY UP SHOOT DENGAN MENGGUNAKAN METODE BAGIAN PERBAGIAN. SEGAR, 7, 54-63.

Argaheni, N. B. (2020). Sistematik Review: Dampak Perkuliahan Daring Saat Pandemi COVID-19 Terhadap Mahasiswa Indonesia. PLACENTUM: Jurnal IImiah Kesehatan Dan Aplikasinya, $8(2), \quad 99$. https://doi.org/10.20961/placentum.v8i 2.43008

Beban, T. I. M., \& Dosen, K. (2020). Rubrik beban kerja dosen (bkd).

Brown, A. H., \& Brown, A. H. (2016). Making Better Use of Technology by Creating a Personal Taxonomy of Instructional Media. The Clearing House: A Journal of Educational Strategies, Issues and Ideas, 8655(April). https://doi.org/10.1080/000986501095 99226

Cucinotta, V. V. (2020). WHO Declares COVID-19 a Pandemic. Acta Biomedica, . 2020; 91, : 157-160.

Donovan, M. (2010). Youth Basketball 101 Drills.

FIBA. (2018). Official Basketball Rules 2018.

Hampson, N., King, L., Eriksson, L. M., \& Smee, H. (2020). The effects of relaxation training on depression and anxiety in people living with long-term neurological conditions. Disability and Rehabilitation, 42(15), 2100-2105. https://doi.org/10.1080/09638288.2018 .1554009

Ilham, M., \& Oktafiranda, N. D. (2021). PENGEMBANGAN BAHAN AJAR MATA KULIAH TEORI DAN PRAKTIK BOLA VOLI BERBASIS E-LEARNING. 1(1), 105-112.

Muskania, R., \& Zulela MS. (2021). Realita Transformasi Digital Pendidikan di Sekolah Dasar Selama Pandemi Covid-19. Jurnal Pendidikan Dasar Nusantara, 6(2), 155-165. https://doi.org/10.29407/jpdn.v6i2.1529 8

Rosnaeni, R., \& Prastowo, A. (2021). Kendala Implementasi Pembelajaran Daring di
Sekolah Dasar pada Masa Pandemi Covid-19: Kasus di SDN 24 Mecanang Kabupaten Bone. Jurnal Basicedu, 5(4), 2241-2246.

Subiakto, H. (2013). Internet untuk pedesaan dan pemanfaatannya bagi masyarakat The usage of internet for the village and villagers.

Vic Amber. (2012). Petunjuk Untuk Pelatih dan Pemain Bola Basket. 